\title{
Analysis of Iron Production Technology of Army against Japanese through Slag from Saengsoegol Iron Production Site
}

\author{
Minjae Kim', Kwangyong Chung,", \\ ${ }^{1}$ Department of Heritage Conservation and Restoration, Graduate School of Cultural Heritage, Korea National University of \\ Cultural Heritage, Buyeo 33115, Korea \\ ${ }^{2}$ Institute of Conservation Science, Korea National University of Cultural Heritage, Buyeo 33115, Korea
}

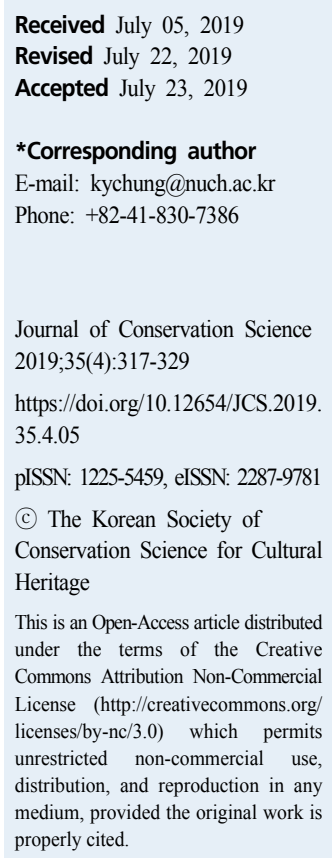

ABSTRACT Slag was collected from the iron-producing furnace site in Saengsoegol, Baegun mountain, where iron was manufactured by a righteous army against Japan in the Gwangyang region; then, the iron-manufacturing technique of the early modern period was investigated through scientific analysis. In the microstructure analysis results of the selected samples, iron bloom was mainly observed together with magnetite and fayalite. In the component analysis results of the compounds, it was confirmed that the furnace was built by using gangue of alkali feldspar or plagioclase series, and the ironmaking work was performed at a high temperature of at least $1050^{\circ} \mathrm{C}$, because mullite was identified together with cristobalite and hercynite. Based on the chemical composition, it was speculated that low-grade iron ores were used as raw materials, and it seemed that the yield was low, because the total Fe content of the smelting slag samples was $37.72-49.93 \%$. It was difficult to confirm whether a slag former was used, and it seemed that materials easily obtained nearby were used when the furnace was built, without considering the corrosion resistance. It appeared that the ironmaking work was performed at the Gwangyang Saengsoegol iron-producing furnace based on the direct ironmaking method in an environment that could escape the vigilance of the Japanese Empire to produce weapons that would be used for the resistance against Japan. It seemed that there was neither an advanced ironware production system nor a mass production system, and small-scale works were performed in short periods of time.

Key Words Iron production, Smelting, Slag, Gwangyang Saengsoegol, Japanese colonial period, Army against Japanese

\section{INTRODUCTION}

The technologies for producing and processing metals have been closely related to the history of the human race from the development of civilization to the progress of modern nations (Chung, 2009). Because iron, among the many kinds of metals, has large deposits and high production efficiency, its importance has been immense(Shin, 2000).

In Korea, the ironmaking technique was introduced by Gojoseon (Ancient Joseon) in the third to second centuries $\mathrm{BCE}$, and the technology level was so advanced in the three Kingdoms period that the ironmaking technique was spread to
Japan(Rho, 2000). However, the ironmaking technique passed down from ancient times gradually declined in the $19^{\text {th }}$ century, the latter period of Joseon, because of the Confucian ideology and social atmosphere. During the Japanese occupation period(1910-1945), the production and use of ironware were limited because of the oppression of the Japanese Empire, and, because industry and the economy were depressed due to plundering by the imperialist powers, the traditional ironmaking technique was lost(Kim, 2017).

In the $1980 \mathrm{~s}$, the ruins of ironmaking sites began to be excavated, and the inflow and development process of ironware culture in the ancient Korean peninsula started to be 
investigated, targeting iron artifacts, to shed light on the traditional ironmaking techniques(Yoon and Shin, 1981; 1982). Furthermore, studies of smelting techniques were conducted through microstructure observation to investigate the ironware production, processing, and periods of use(Chung, 2001; Park et al., 2001). Thereafter, scientific analyses have been performed for the iron artifacts excavated from the ruins. However, there are difficulties in analyzing the material properties of base metals because of the corrosion of excavated artifacts and limited sample collection resulting from the principle of preserving the original form of cultural property.

In the process of overcoming these limitations, some studies have found that slag produced during the smelting process have different characteristics from each other because of such factors as the materials and ironmaking temperature, and the smelting techniques were investigated by applying metallurgical analysis or chemical analysis(Chung, 2006). Recently, studies have been actively conducted for archeological restoration experiments based on the results of analyzing ironware and slag excavated from the ruins of iron production sites corresponding to the periods preceding the Joseon period to reproduce the traditional smelting technique that no longer exists. However, there have been relatively few studies on the smelting process of the early modern period compared with that of ancient periods(Kim, 2017).

Therefore, in this study, on-site investigation was conducted at the Gwangyang Saengsoegol iron-producing furnace site, where the ironmaking process was used to manufacture weapons in the early $20^{\text {th }}$ century. Scientific analysis was performed by collecting samples related to the smelting process to investigate the early modern period iron production technique used by the righteous army against Japan in the Gwangyang region.

\section{RESEARCH TARGET AND METHOD}

\subsection{Research target}

At the end of $19^{\text {th }}$ century, the sovereignty of Joseon was lost because of the aggression of Japan, which had become a powerful country in the early modern era, and, resisting Japan, the grass roots of Joseon engaged in the righteous army against Japan Movement all over the country. The nationwide righteous army activities were most active in 1907, a period when the latter-period righteous armies resisted the forced abdication of emperor Gojong and forced signing of the Korea -Japan New Treaty. The number of people who participated in the righteous armies at that time was estimated to be approximately 140,000 , and, based on the references of the Japanese Empire that recorded 14,566 as the number of righteous army soldiers they massacred from July 1907 to November 2008, it can be estimated that a great number of righteous army soldiers were actively involved in the protest at that time(Hong, 2004). In the military and police records of the Japanese Empire in 1908 and 1909, 24.7\% of people who participated in the righteous army resistance nationwide were in the Jeolla-do region, and the number of battles corresponded to $25 \%$ of the national total. This indicates that the righteous armies of the Honam region were quite active(National Institute of Korean History, 1965).

In September 1907, the Japanese Empire enforced the firearms and explosives control act and the informing on weapons act so that people would not be able to resist the colonial rule. Thus, the complete disarmament of Joseon people policy restricted the weapon supply to the righteous armies by prohibiting ironware production and possession(Hong, 2004). In response, Byeong-hak Hwang(1876.1.11.-1931.4.23.), a general of a righteous army, raised an army at the Baegun mountain in August, 1908 and made an iron- producing furnace in Saengsoegol to procure weapons for battles. It is estimated that the furnace was operated until the army was broken up by the operation for the massive subjugation of southern Korea(1909.9.1.-1909.10.30.) in the following year (Gwangyang City Hall, 1999).

The Gwangyang Saengsoegol iron-producing furnace site was discovered at a $535 \mathrm{~m}$ position from the foot of Eokbul peak of Baegun mountain by a research group of the Suncheon National University Museum while investigating the historical sites of the armed resistance against the Japanese occupation in the Gwangyang region. It seemed that the furnace was located at a steep slope of high altitude to avoid the Japanese vigilance. Forest resources were abundant in the area, and a valley that had water that could be used was close by at the front side of the iron-producing furnace(Gwangyang City Hall, 2012). It was confirmed to be a " $U$ " shaped and stone-walled iron-producing furnace in 2011 through excavation by the Jeonnam Cultural Property Research Center(Figure 1). The furnace had a size of approximately $100 \mathrm{~cm}$ at the bottom and 


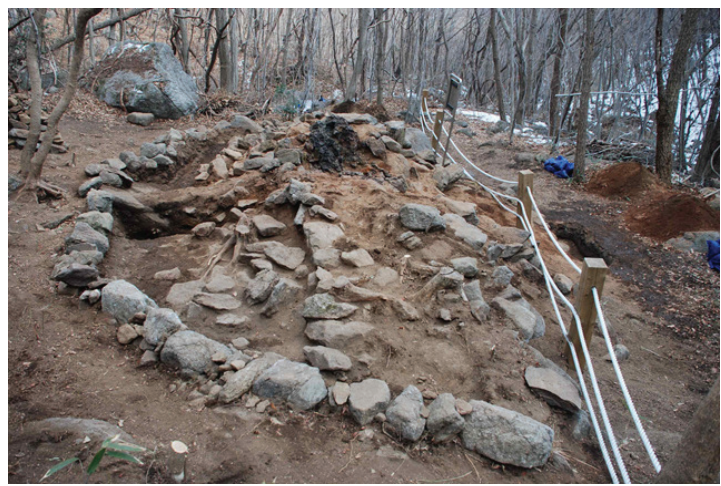

Figure 1. Scenery of iron producing furnace after investigation of Jeonnam Cultural Property Research Center.

about $90 \mathrm{~cm}$ height, and the furnace walls were composed of stones and clay(Jeonnam Cultural Property Research Center, 2011). At present, the east, west, and north walls of the furnace still remain, but the north wall is mostly washed away. Because slag was deposited inside the furnace and soil burnt by the high temperature was observed at the lower part, it was determined that ironmaking work was performed there(Figure 2).

\subsection{Research method}

Through the on-site investigation, the southeast and northwest side furnace walls were classified as SE and NW, and the furnace floor samples were marked as UN. The hiking trail area in front of the furnace was classified as FR, the open space in the back as BA, and the entrance side of the furnace as EN. Then, the slag and charcoal related to the ironmaking work were directly collected. Through the results of observing with the naked-eye, seven samples of furnace walls, five samples of furnace floor, five samples of smelting slag, six samples of reduced iron, and two samples of iron ores were selected, and their images are shown in Table 1.

The microstructure of each sample was observed using a metallurgical microscope(DM2500M, Leica, DEU). For moredetailed microstructure and chemical composition, every sample was analyzed by selecting the analysis position after coating it with $\mathrm{Au}$ and calibrating based on $\mathrm{Cu}$ using a scanning electron microscope (SEM)(JSM-5910LV, JEOL, JPN) and energy dispersive spectrometer (EDS)(INCA, Oxford Instruments, GBR).

To examine the compound state and chemical composition of samples related to the furnace and slag produced in the

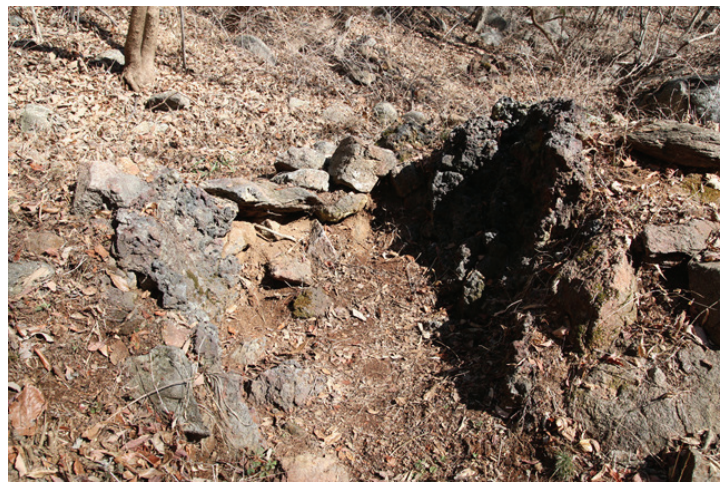

Figure 2. Field investigation of Gwangyang Saengsoegol iron-producing furnace in 2016.

ironmaking process, each sample was turned into powder by pulverizing it three times for $1 \mathrm{~min}$ each at $20 \mathrm{~Hz}$ using a sample pulverizer(MM200, Retcsh, DEU). Selection was made from the pulverized powder in $200 \mu \mathrm{m}$ units.

An X-ray diffraction analyzer(X'Pert PRO MPD, Philips, NLD) was used to investigate the compound state in each sample. For the analysis, the $2 \theta$ value was set to $5^{\circ}-70^{\circ}$ based on $\mathrm{Cu}$, and the step size and scan speed were set to $0.03^{\circ}$ and $1 \mathrm{~s} /$ step, respectively. The voltage and the current were set to $40 \mathrm{kV}$ and $40 \mathrm{~mA}$, respectively, and the measurement was performed by rotating each sample at a speed of $1 / 16 \mathrm{~s}$ to exclude the directivity of minerals in the sample.

The chemical composition of each sample was analyzed by using a wavelength dispersive X-ray fluorescence spectrometer (S8 TIGER, Bruker, DEU). The loss of ignition was measured by heating at $1200^{\circ} \mathrm{C}$, and the qualitative and quantitative analysis was conducted by fabricating glass beads to minimize the nonuniformity of samples.

\section{RESEARCH RESULTS}

\subsection{Microstructure}

Tables 2 and 3 show the microstructures of the NW1 and FR4 samples of the furnace walls. In the furnace wall samples of the Saengsoegol iron-producing furnace, polygonal white grains were observed along with structures of gray long column-shaped fayalite and dendritic magnetite. In the SEMEDS analysis results of NW1 and FR4 samples, the analysis positions 1 and 2 of the NW1 sample seemed to be fayalite and iron particles, respectively, and the gray background at 
Table 1. Slag sample from Gwangyang Saengsoegol iron-producing furnace

\begin{tabular}{|c|c|c|c|c|}
\hline Furnace wall & Bottom of furnace & Smelting slag & Reduced iron & Iron ore \\
\hline SE6 & SE7 & SE1 & SE2 & BA3 \\
\hline NW1 & SE8 & SE4 & SE3 & EN2 \\
\hline NW5 & UN2 & UN3 & SE5 & \\
\hline NW6 & UN4 & FR1 & SE9 & - \\
\hline UN5 & BA1 & FR2 & NW2 & - \\
\hline FR3 & - & - & NW3 & - \\
\hline FR4 & - & - & NW4 & - \\
\hline
\end{tabular}

position 3 corresponded to the glass phase. The analysis positions 1 and 2 of the FR4 sample seemed to be magnetite, and position 3 was estimated to be wüstite of fine dendritic phase, but it seemed surrounding components were detected together because of the narrow analysis range. Position 4 corresponded to the glass phase.

The samples of the furnace floor showed similar patterns to those of the samples of the furnace walls. The SE7 sample collected from the southwest floor part of the furnace showed that magnetite of different sizes was broadly distributed on the glass phase of dark color, as shown in Table 4. In the SEMEDS analysis results, the remaining four places, excluding the analysis position 5, which corresponded to the glass phase, were all estimated to be magnetite structures. Although there 
Analysis of Iron Production Technology of Army Against Japanese through Slag from Saengsoegol Iron Production Site / Minjae Kim, Kwangyong Chung | 321 -

Table 2. Microstructure and SEM-EDS analysis results of the NW1 from Furnace wall

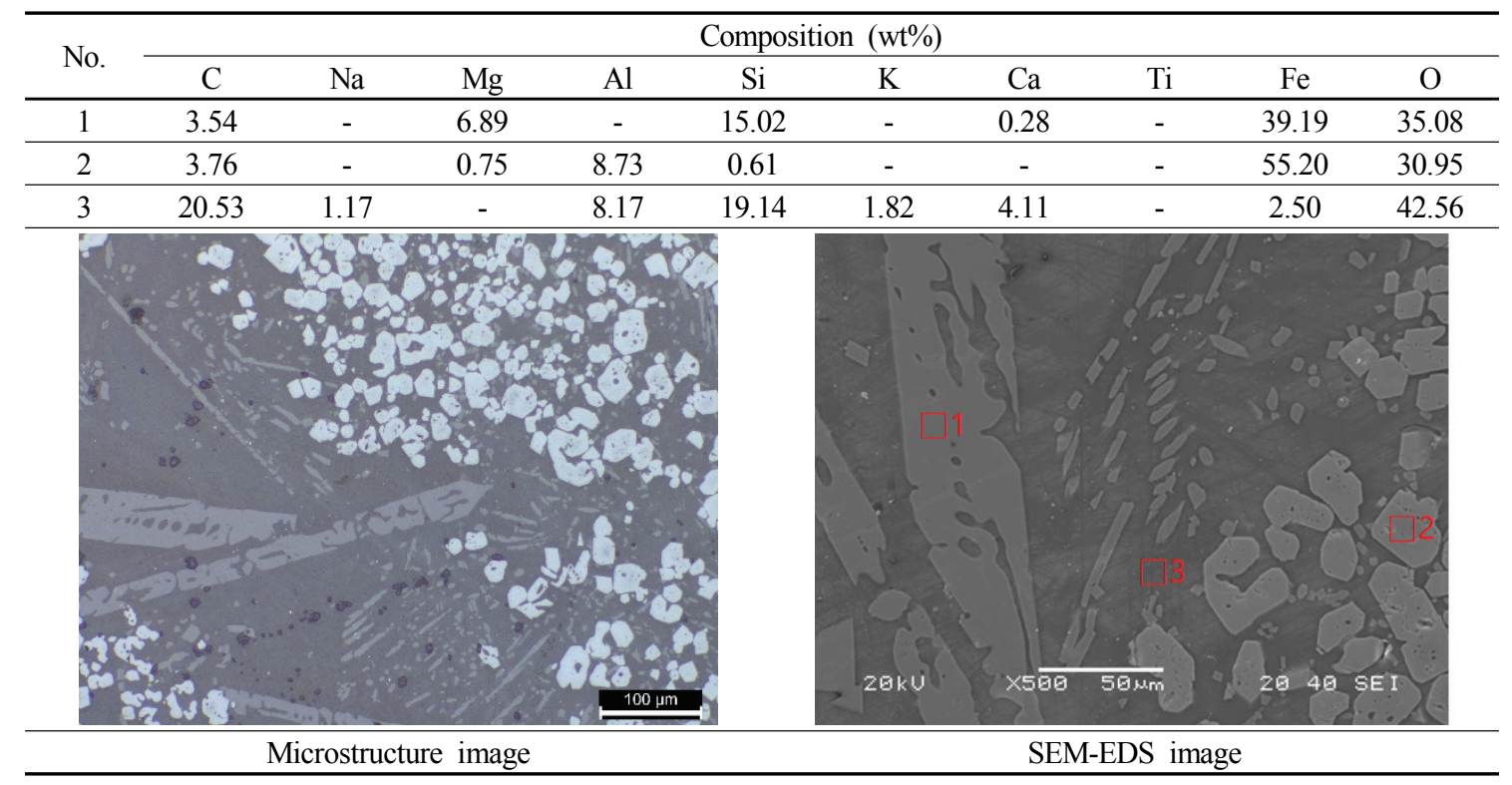

Table 3. Microstructure and SEM-EDS analysis results of the FR4 from Furnace wall

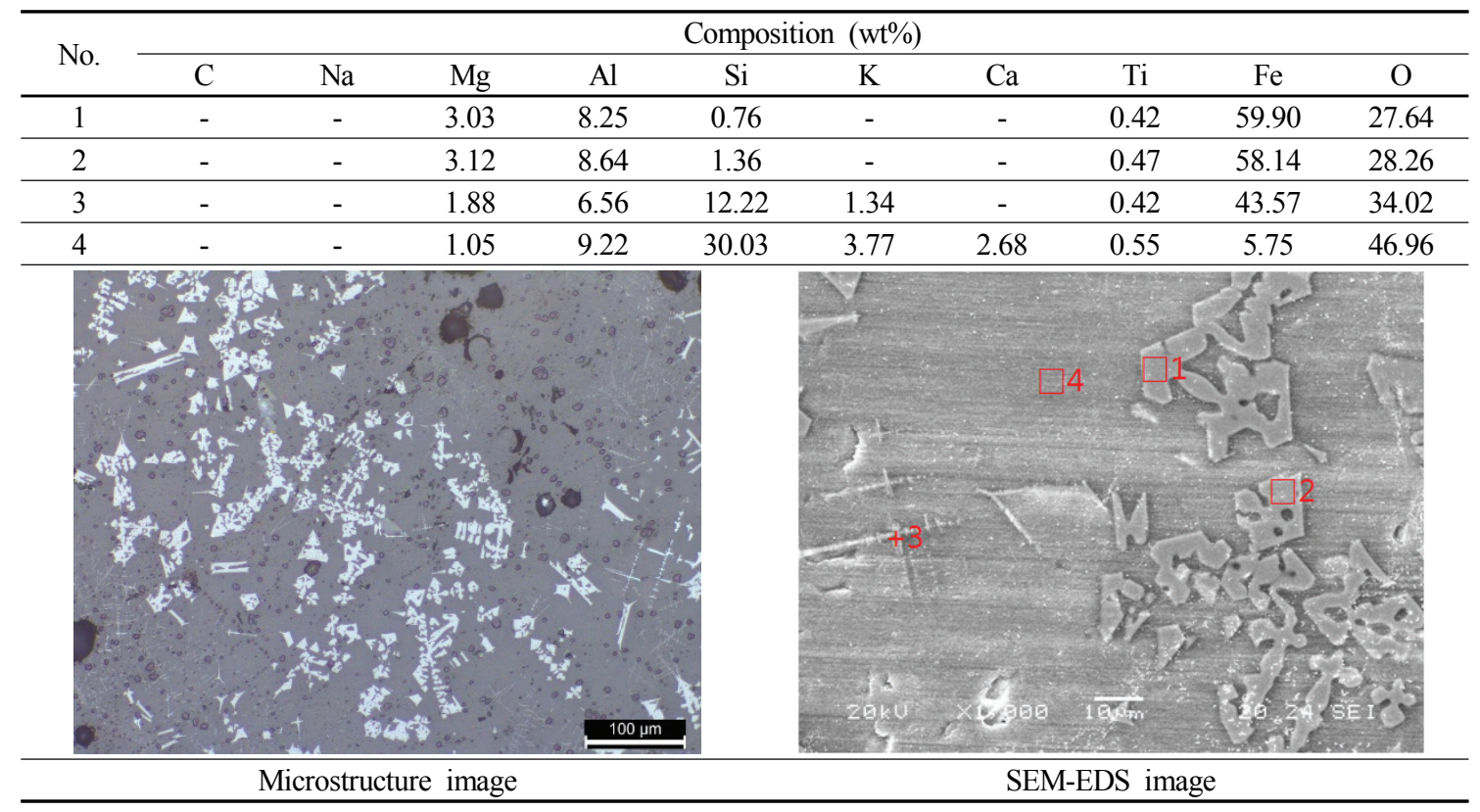

were some differences in the component contents of each structure, a majority had Fe content of more than $50 \%$.

Such structures as fayalite and magnetite were mainly observed in the smelting slag samples. The microstructure observation results of SE4 confirmed that it was composed of long column-shaped fayalite together with polygonal white grains(Table 5). In the results of observing the microstructures using the SEM and performing EDS analysis, the analysis positions 1 and 2 seemed to be polygonal magnetite particles having similar $\mathrm{Fe}$ contents, and position 3 seemed to be fayalite. Positions 4 and 5 were estimated to be wüstite of dendritic phase, but the components and contents of the glass phase appeared to be detected together because the structure was tiny. 
Table 4. Microstructure and SEM-EDS analysis results of the SE7 from Bottom of furnace

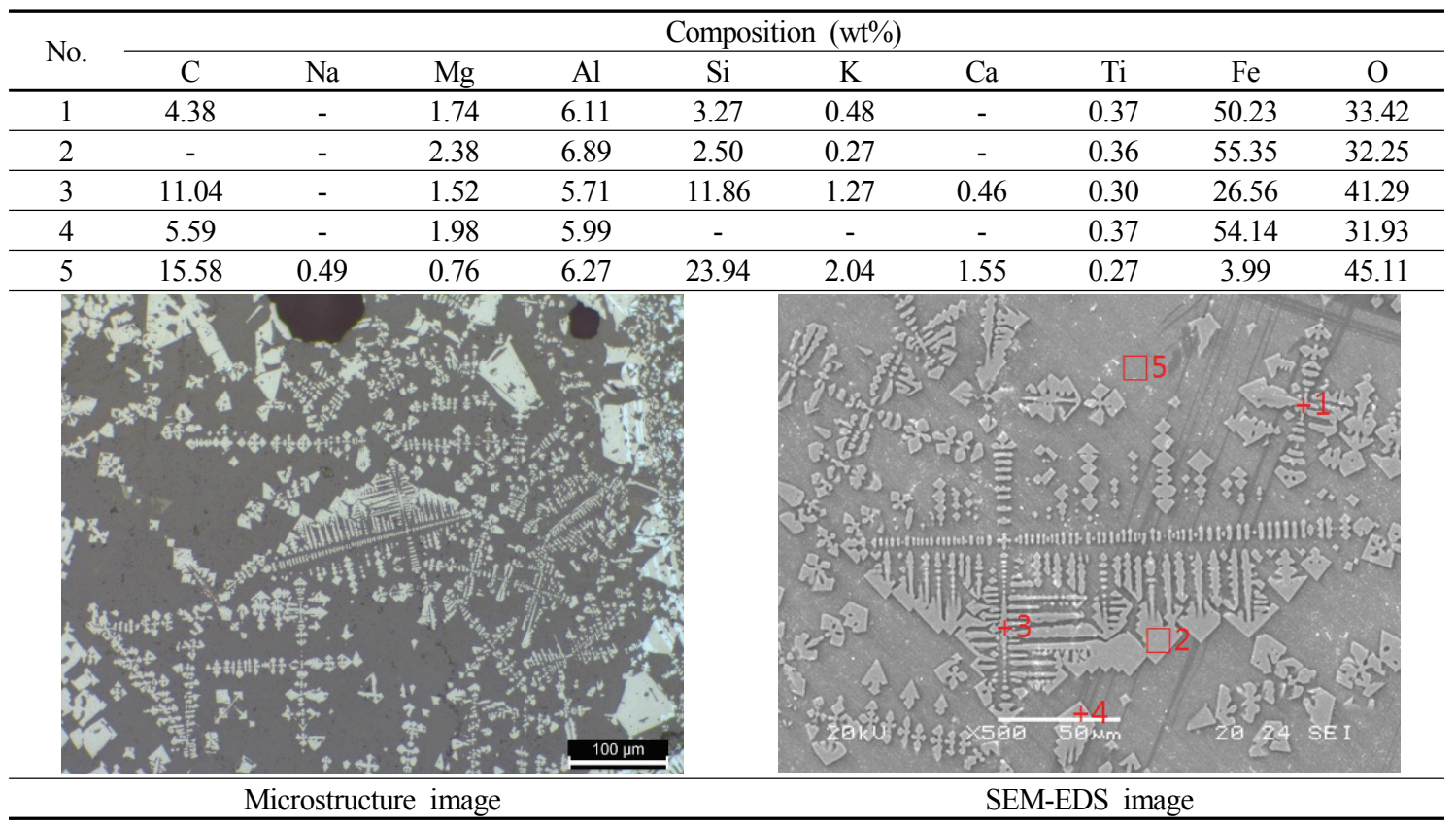

Table 5. Microstructure and SEM-EDS analysis results of the SE4 from Smelting slag

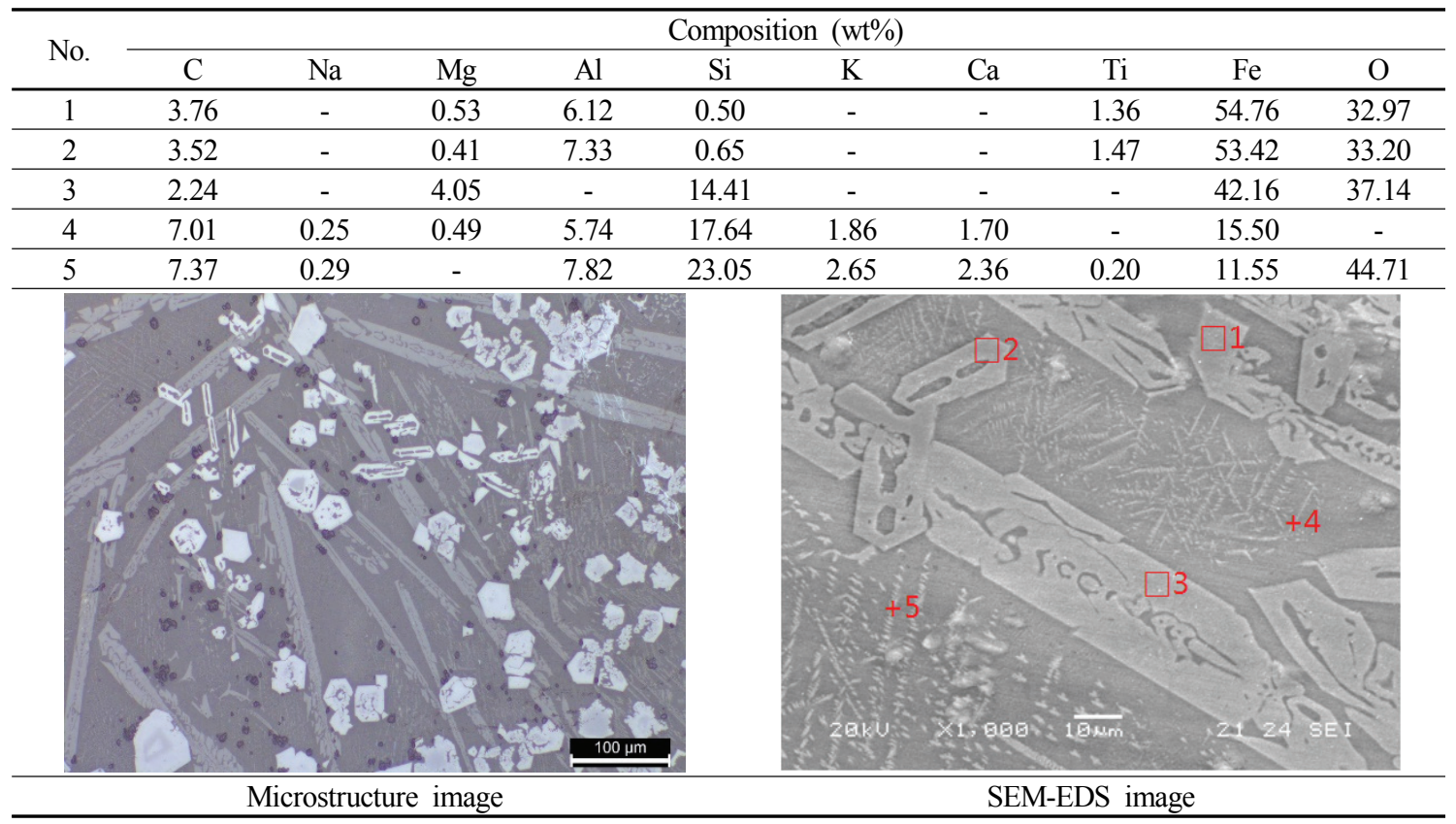

A porous iron bloom structure was observed along with fayalite in the majority of the reduced iron samples. The microstructure observation results of SE3 and SE9 collected from the inside of the furnace showed a porous iron structure together with a gray long column-shaped structure, such as
SE3 in Table 6, or a wide distribution of porous iron structure, such as SE9 in Table 7. In the results of the SEM-EDS analysis, positions 1 and 2 on SE3 seemed to be fayalite, nonmetal inclusion, as shown in Table 6; the iron structure of position 3 was estimated to have an iron bloom structure, a type of 
Table 6. Microstructure and SEM-EDS analysis results of the SE3 from Reduced iron

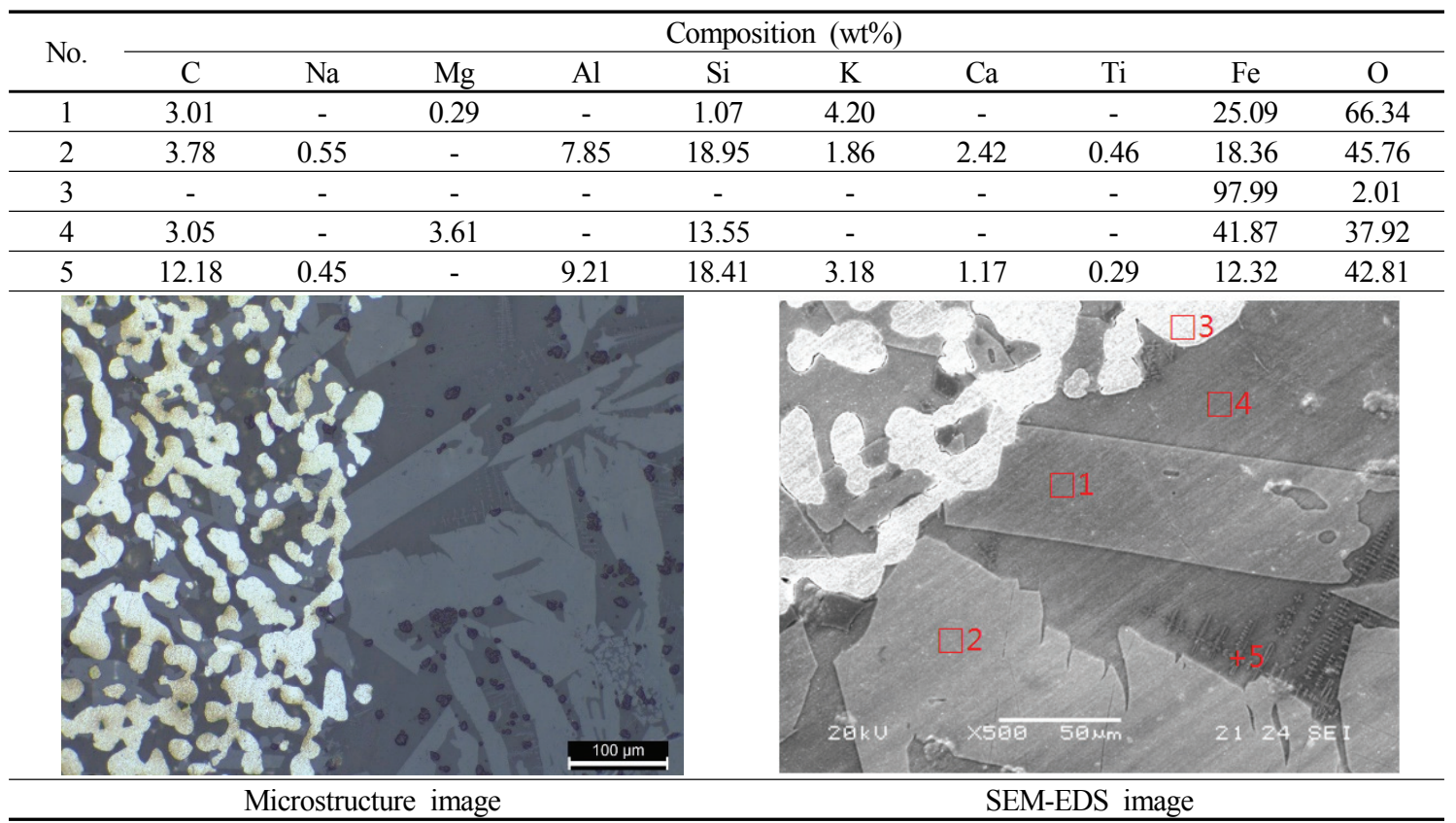

Table 7. Microstructure and SEM-EDS analysis results of the SE9 from Reduced iron

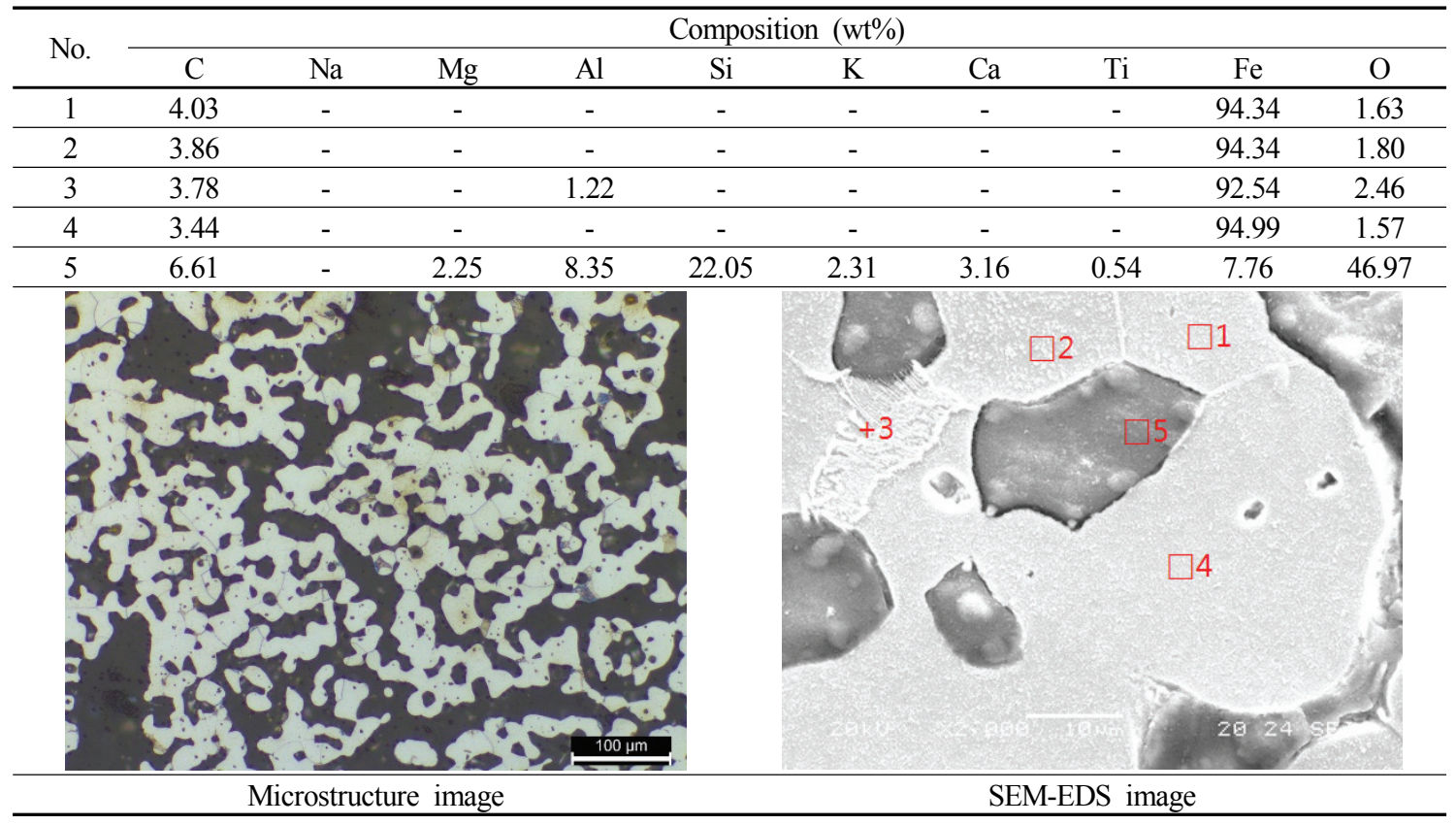

pure iron, and its carbon content was on the low side. Position 4 corresponded to the glass phase. Position 5 was estimated to be a structure of fine wüstite, but the components and contents of the glass phase appeared to be observed together because the range was narrow.
As shown in Table 8, cracks in the structure were overall for BA3, an iron ore sample, and, based on the cracks, minerals of white and black phases were divided. In the SEMEDS analysis results, positions 1 and 2, which corresponded to the white color, seemed to be iron particles that had not 
Table 8. Microstructure and SEM-EDS analysis results of the BA3 from Iron ore

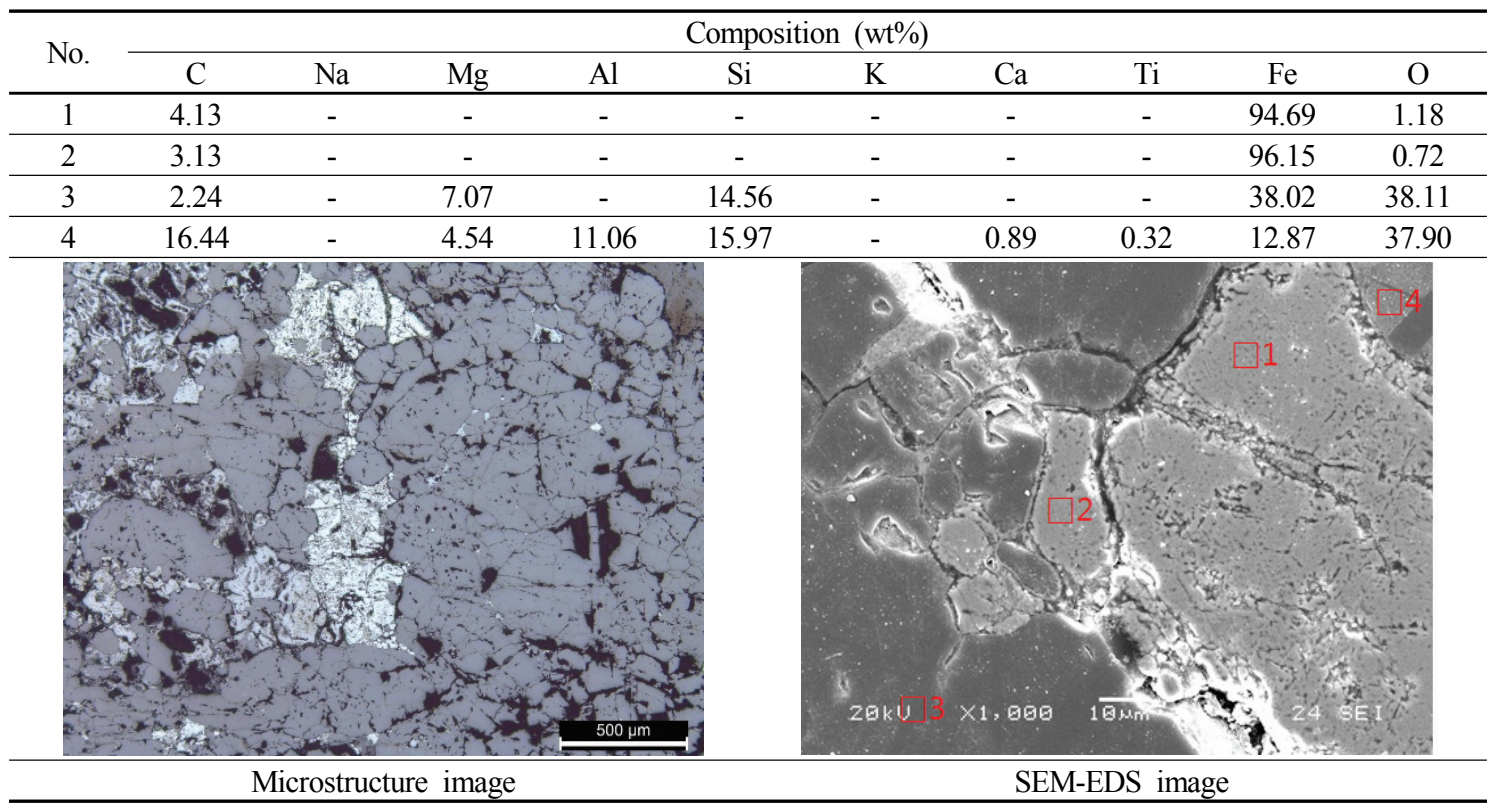

Table 9. Compound analysis result of slag samples from Gwangyang Saengsoegol iron-producing furnace

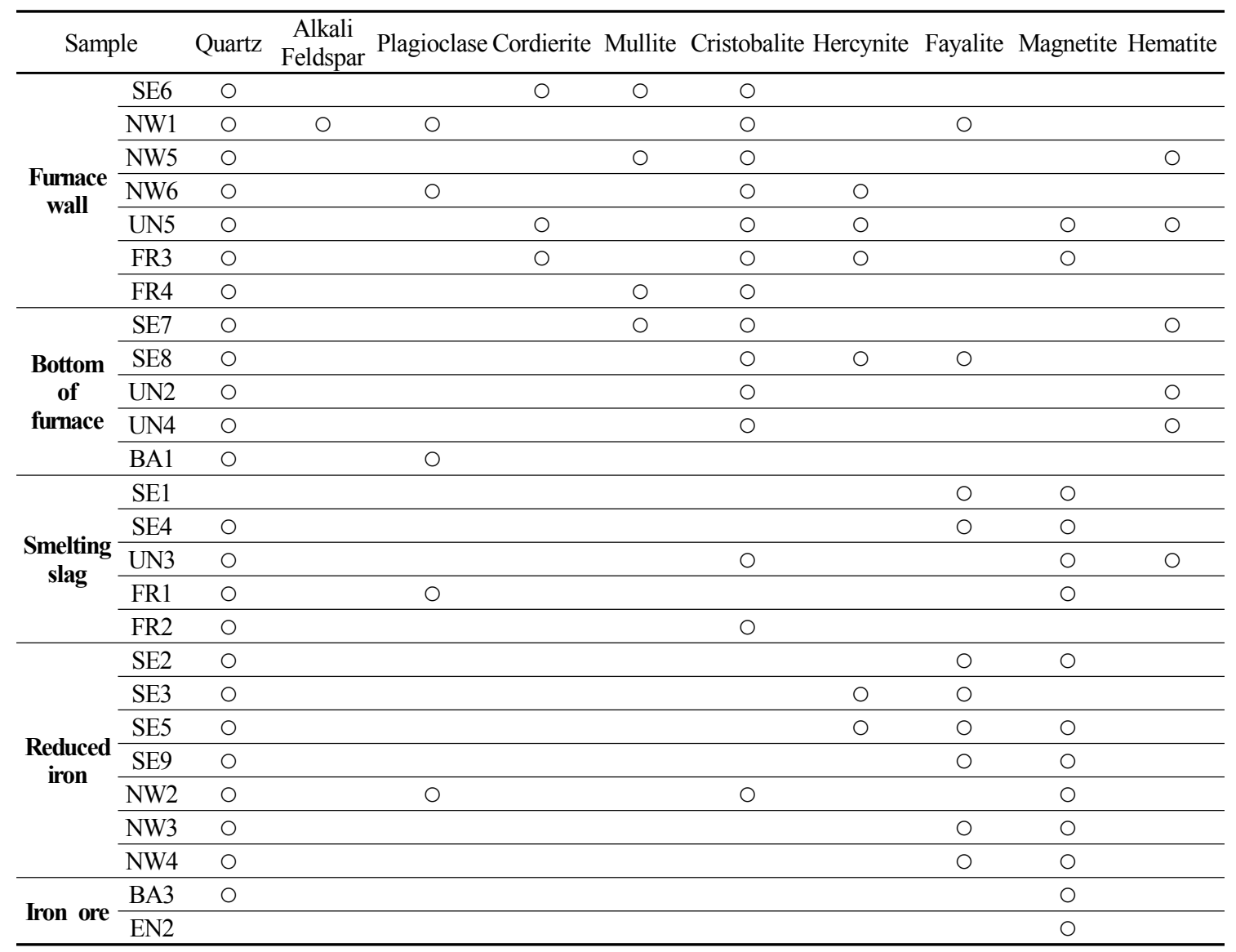


undergone the smelting process, but the Fe content was high. Positions 3 and 4, showing a gray color, corresponded to the glass phase.

\subsection{Compounds}

The compound analysis result of each sample is Figure 3 to 8 and summarized in Table 9. In the sample analysis of the furnace walls and floor, pillar-shaped quartz was observed. Furthermore, alkali feldspar or plagioclase, which are feldspar minerals, were observed partially in NW1 and NW6, indicating the effects of gangue components used for building the furnace walls and floor. High-temperature-indicating minerals, such as mullite and hercynite, were observed along with cristobalite in many samples, indicating that high-temperature processes were performed in the furnace.

In some samples of smelting slag, fayalite was identified in a pillar shape, or quartz and plagioclase were detected, such as in UN3 and FR1. Therefore, it was determined that the components of the raw ores used in the process or the stones composing the walls were mixed into the slag as a result of the high temperature. Except for the FR2 sample, which seemed to be vitrificated, because only quartz and some cristobalite

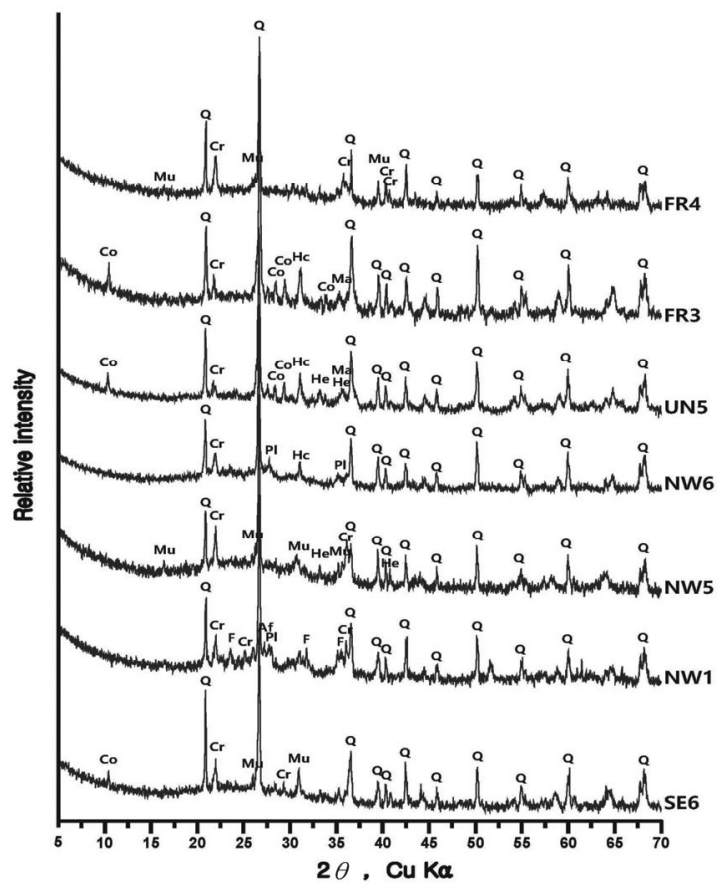

Figure 3. X-ray diffraction patterns of the analyzed samples from the Furnace wall. were detected, every smelting sample showed magnetite or hematite.

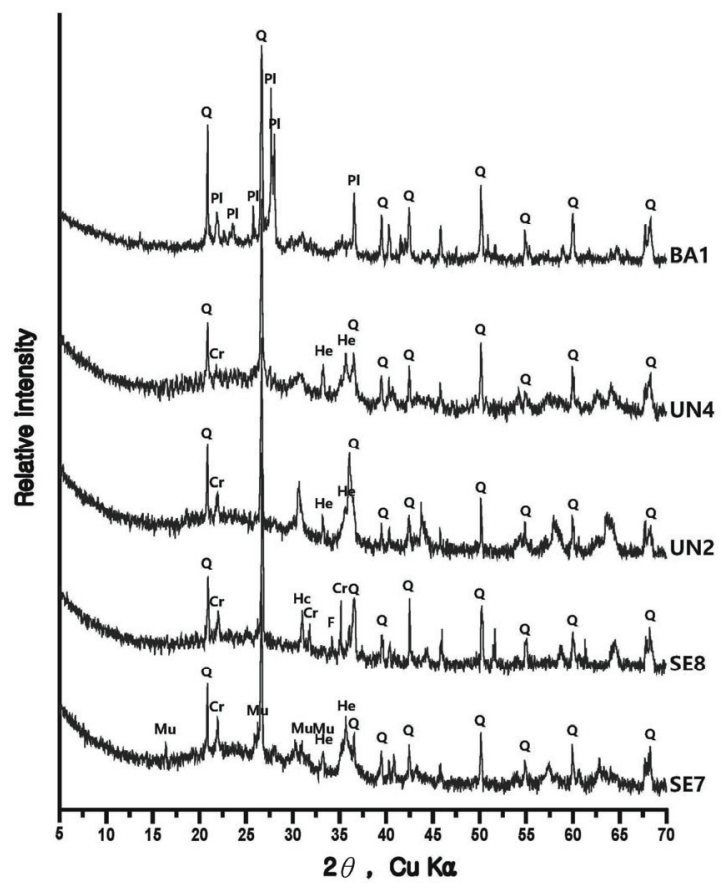

Figure 4. X-ray diffraction patterns of the analyzed samples from Bottom of furnace.

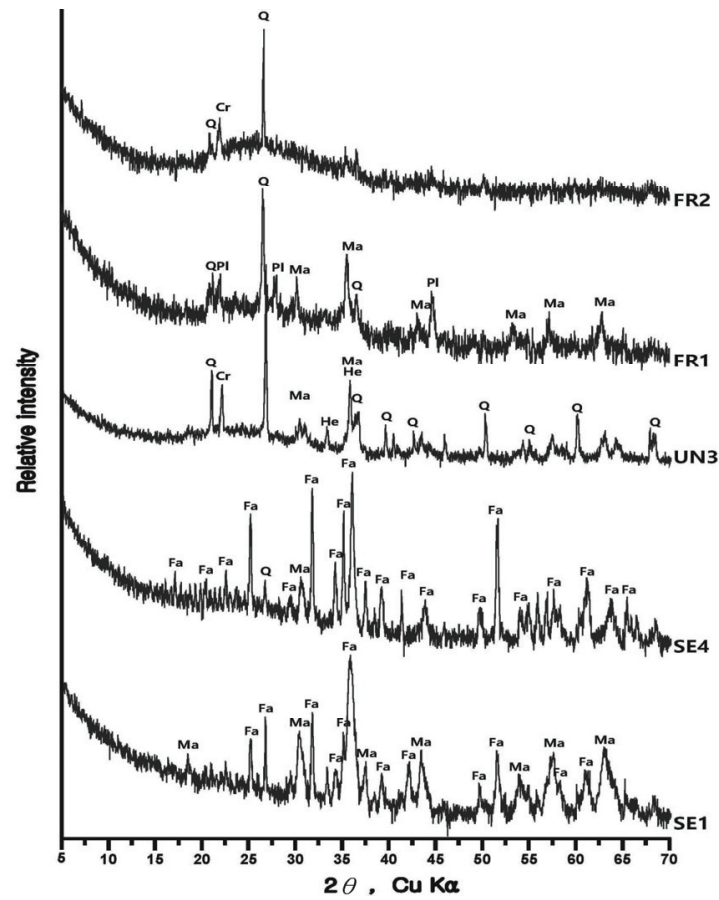

Figure 5. X-ray diffraction patterns of the analyzed samples from Smelting slag. 


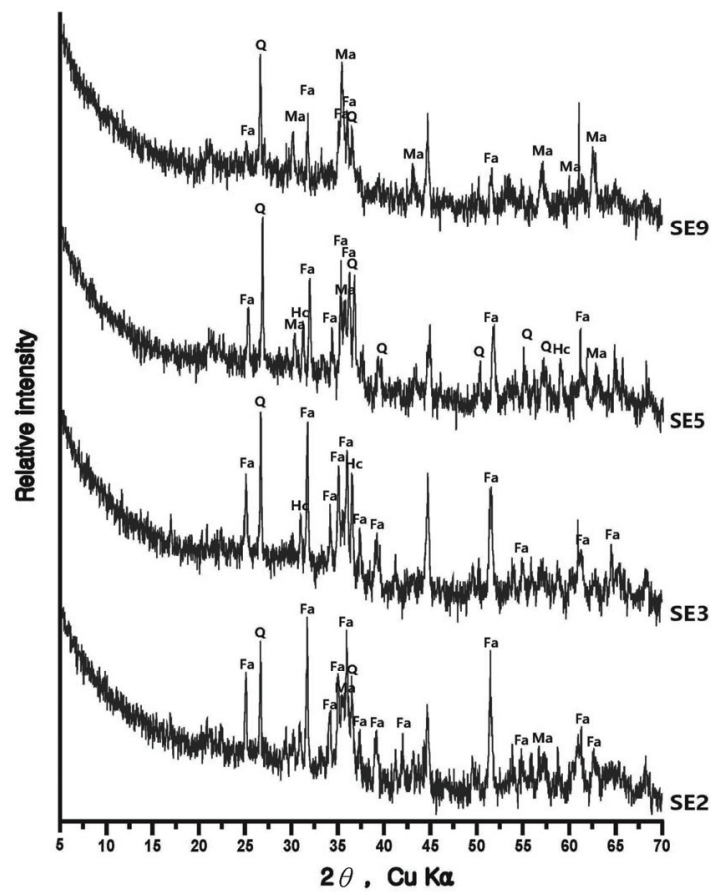

Figure 6. X-ray diffraction patterns of the analyzed samples from Reduced iron 1.

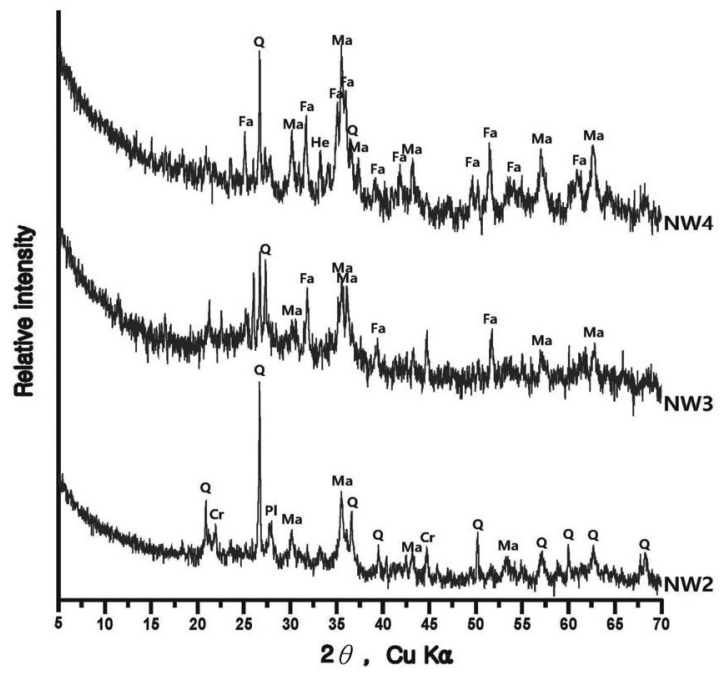

Figure 7. X-ray diffraction patterns of the analyzed samples from Reduced iron 2 .

The samples collected from the reduced iron that was deposited inside the furnace also showed cristobalite and hercynite, indicating that they underwent high temperature. Magnetite or fayalite was identified in every sample, and, because magnetite was detected in the iron ore samples, it was determined that there was a correlation between the raw material

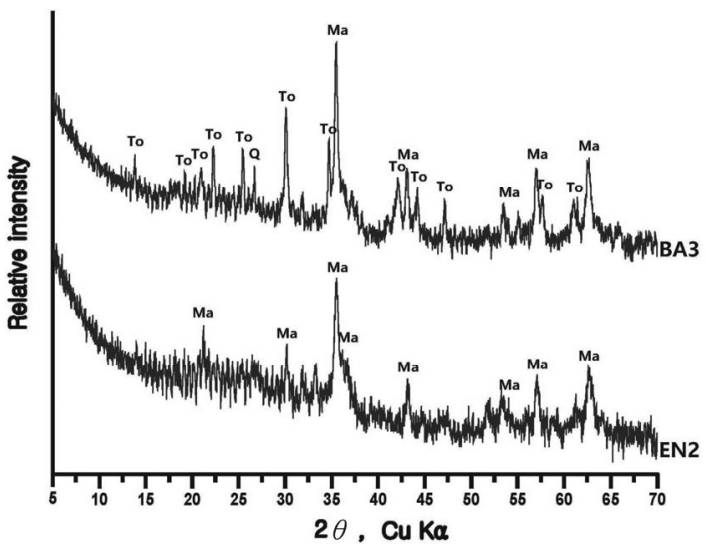

Figure 8. X-ray diffraction patterns of the analyzed samples from Iron ore.

used in the ironmaking work and the smelting slag or reduced iron samples that had undergone the ironmaking process.

\subsection{Major components}

In the results of major component analysis investigating the chemical composition of analysis target samples(Table 10), the total $\mathrm{Fe}$ content of the furnace wall samples was 3.05-9.44\%, whereas that of the furnace floor sample was $4.13-15.61 \%$, showing similar or lower values. The reason why the $\mathrm{Fe}$ content of the samples deposited on the furnace floor was similar to or higher than that of the furnace walls was because the Fe component, which was not separated from the slag in the process of producing reduced iron, remained at the bottom of furnace, which was lower than the furnace wall.

$\mathrm{TiO}_{2}, \mathrm{~V}_{2} \mathrm{O}_{5}$, and $\mathrm{ZrO}_{2}$, which would be observed if iron sand were used as a raw material, were barely detected in every sample, and, based on the comparison with the microstructure and compound analysis results of collected iron ore and smelting slag samples, it was concluded that iron ores were used as raw materials(Yoon, 1986).

The total Fe content of UN3 and FR2 among the smelting slag was $12.17 \%$ and $18.90 \%$, respectively, indicating that separation of the $\mathrm{Fe}$ component was relatively easy compared with the other smelting slag samples. The total Fe content of SE1, SE4, and FR1 was $49.71 \%, 37.72 \%$, and $49.93 \%$, respectively. They were similar to the Fe content level of $17-$ $40 \%$ observed in ancient ironmaking, but, considering that they were of low-grade iron ores since the $\mathrm{Fe}$ contents contained in the iron ore samples were only $49.03 \mathrm{wt} \%$ and $60.89 \mathrm{wt} \%$, 
Analysis of Iron Production Technology of Army Against Japanese through Slag from Saengsoegol Iron Production Site / Minjae Kim, Kwangyong Chung I 327

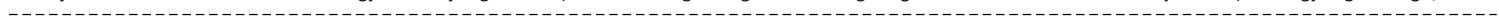

Table 10. Chemical composition analysis of slag samples from Gwangyang Saengsoegol

\begin{tabular}{|c|c|c|c|c|c|c|c|c|c|c|c|c|c|}
\hline \multirow{2}{*}{\multicolumn{2}{|c|}{ Sample }} & \multicolumn{11}{|c|}{ Composition (wt\%) } & \multirow{2}{*}{$\begin{array}{c}\text { Total } \\
\text { Fe }\end{array}$} \\
\hline & & $\mathrm{TiO}_{2}$ & $\mathrm{Fe}_{2} \mathrm{O}_{3}$ & $\mathrm{CaO}$ & $\mathrm{MgO}$ & $\mathrm{SiO}_{2}$ & $\mathrm{Al}_{2} \mathrm{O}_{3}$ & $\mathrm{Cr}_{2} \mathrm{O}_{3}$ & $\mathrm{~K}_{2} \mathrm{O}$ & $\mathrm{MnO}$ & $\mathrm{Na}_{2} \mathrm{O}$ & $\mathrm{P}_{2} \mathrm{O}_{5}$ & \\
\hline \multirow{7}{*}{$\begin{array}{c}\text { Furnace } \\
\text { wall }\end{array}$} & SE6 & 0.70 & 10.90 & 0.45 & 2.08 & 63.15 & 19.06 & 0.01 & 3.47 & 0.08 & 0.29 & 0.08 & 7.62 \\
\hline & NW1 & 0.56 & 13.50 & 1.56 & 2.17 & 61.37 & 15.58 & 0.01 & 4.73 & 0.06 & 1.07 & 0.10 & 9.44 \\
\hline & NW5 & 0.78 & 11.57 & 1.67 & 1.98 & 62.96 & 17.05 & 0.01 & 3.85 & 0.09 & 0.49 & 0.16 & 8.09 \\
\hline & NW6 & 0.44 & 4.36 & 0.86 & 1.69 & 72.74 & 14.18 & 0.01 & 4.26 & 0.04 & 1.51 & 0.06 & 3.05 \\
\hline & UN5 & 0.82 & 11.25 & 0.30 & 1.81 & 65.72 & 16.60 & 0.02 & 2.56 & 0.07 & 0.35 & 0.07 & 7.87 \\
\hline & FR3 & 0.69 & 10.16 & 0.48 & 1.94 & 64.35 & 18.81 & 0.01 & 3.17 & 0.06 & 0.27 & 0.07 & 7.10 \\
\hline & FR4 & 0.63 & 13.43 & 1.91 & 1.69 & 62.64 & 15.91 & 0.01 & 3.09 & 0.08 & 0.66 & 0.12 & 9.39 \\
\hline \multirow{5}{*}{$\begin{array}{c}\text { Bottom } \\
\text { of } \\
\text { furnace }\end{array}$} & SE7 & 0.82 & 16.63 & 0.88 & 1.91 & 58.65 & 18.05 & - & 3.12 & 0.08 & 0.46 & 0.11 & 11.63 \\
\hline & SE8 & 0.66 & 22.32 & 1.06 & 1.74 & 55.38 & 16.44 & 0.01 & 3.01 & 0.08 & 0.28 & 0.11 & 15.61 \\
\hline & UN2 & 0.83 & 20.29 & 1.18 & 2.15 & 55.16 & 17.61 & 0.01 & 2.67 & 0.09 & 0.41 & 0.12 & 14.19 \\
\hline & UN4 & 0.70 & 14.27 & 1.40 & 1.88 & 60.31 & 16.54 & 0.01 & 3.93 & 0.07 & 0.39 & 0.13 & 9.98 \\
\hline & BA1 & 0.57 & 5.90 & 1.46 & 1.43 & 68.08 & 15.61 & - & 5.25 & 0.05 & 1.61 & 0.07 & 4.13 \\
\hline \multirow{5}{*}{$\begin{array}{l}\text { Smelting } \\
\text { slag }\end{array}$} & SE1 & 0.54 & 71.08 & 0.73 & 1.07 & 20.81 & 8.80 & 0.01 & 0.57 & 0.06 & 0.08 & 0.08 & 49.71 \\
\hline & SE4 & 0.50 & 53.94 & 1.77 & 1.73 & 33.18 & 10.58 & 0.02 & 1.80 & 0.08 & 0.39 & 0.14 & 37.72 \\
\hline & UN3 & 0.68 & 17.40 & 2.08 & 1.88 & 58.59 & 15.41 & 0.01 & 3.51 & 0.08 & 0.46 & 0.17 & 12.17 \\
\hline & FR1 & 0.40 & 71.39 & 3.54 & 1.42 & 25.12 & 7.57 & 0.02 & 1.43 & 0.10 & 0.31 & 0.15 & 49.93 \\
\hline & FR2 & 0.68 & 27.03 & 4.62 & 3.67 & 46.13 & 16.97 & 0.00 & 2.76 & 0.20 & 1.06 & 0.10 & 18.90 \\
\hline \multirow{2}{*}{ Iron ore } & BA3 & 0.19 & 70.10 & 0.46 & 2.11 & 17.75 & 9.00 & 0.02 & 0.08 & 0.04 & 0.57 & 0.04 & 49.03 \\
\hline & EN2 & 0.26 & 87.05 & 0.11 & 0.11 & 7.40 & 0.67 & - & 0.08 & 0.05 & 0.04 & 0.08 & 60.89 \\
\hline
\end{tabular}

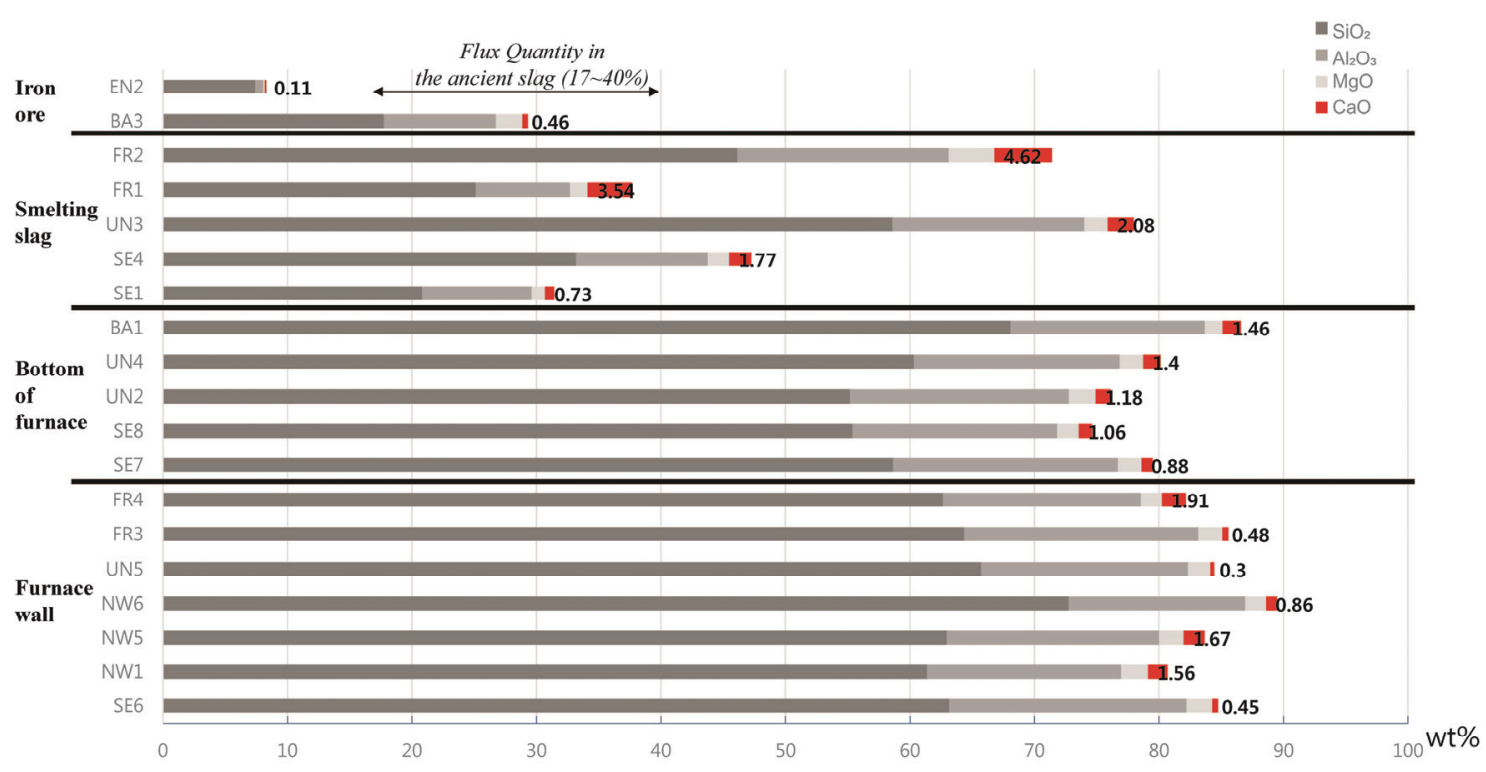

Figure 9. Flux quantity of slag sample from Gwangyang Saengsoegol iron-producing furnace. 
it was difficult to jump to a conclusion that the yield of the ironmaking process was high.

To determine whether a slag former, which facilitates easy separation of impurities, was used to produce the iron efficiently, the analysis can be performed by calculating the flux quantity $\left(\mathrm{SiO}_{2}+\mathrm{Al}_{2} \mathrm{O}_{3}+\mathrm{CaO}+\mathrm{MgO}\right)$. If a calcium compound material is inserted and heated in the process, it turns into $\mathrm{CaO}$, and it is effective for lowering the melting point, decreasing the viscosity, and removing $\mathrm{S}$ and $\mathrm{P}$ components, which are impurities(Choi et al., 1994). In general, if more than $1 \mathrm{wt} \%$ is detected for $\mathrm{CaO}$ content, it is assumed that a slag former has been used(Yoon, 1986; Kang, 2010). The flux quantity of samples collected from the furnace walls and floor was calculated as higher than $74 \%$, and the slag samples also showed $31.41-77.96 \%$, which were very high compared with the flux quantity range shown in the ancient smelting, $17-40 \%$. As shown in Figure 9, $\mathrm{SiO}_{2}$ content was highest among the components of flux quantity, and it accounted for a majority of the total content together with $\mathrm{Al}_{2} \mathrm{O}_{3}$ and $\mathrm{MgO}$. The $\mathrm{CaO}$ content appeared variously from 0.30 to $4.62 \mathrm{wt} \%$, and the $\mathrm{CaO}$ content of the furnace wall and floor samples was approximately $0.30-1.94 \mathrm{wt} \%$, which was uniform, but that of the slag varied in a wide range of $0.73-4.62 \mathrm{wt} \%$.

If fire clay is used as a furnace construction material to endure the iron making process performed at high temperature, the corrosion resistance increases, and whether the fire clay has been used can be determined based on the content of $\mathrm{Al}_{2} \mathrm{O}_{3}$, the main component of fire clay. As shown in Table 10, approximately 14.18-19.06 wt $\%$ was detected for the $\mathrm{Al}_{2} \mathrm{O}_{3}$ content of the furnace wall and floor samples, and this was similar to the content range observed when regular clay was used(Han et al., 1993).

\section{DISCUSSION AND CONCLUSION}

The Gwangyang Saengsoegol iron-producing furnace site is a historical site of an iron-producing furnace constructed by a righteous army raised against the Japanese aggression. Furthermore, it was a basis of latter-period righteous armies that were engaged in resistance activities all over the country, and it is a case in which the operation period and purpose were confirmed(Gwangyang City Hall, 1999). This study investigated the operation environment through field investigation of the Gwangyang Saengsoegol iron-producing furnace site, and the ironmaking technique and characteristics of a righteous army against Japan in the early modern period were examined through scientific analysis of the collected samples.

Because grains having a high $\mathrm{Fe}$ content together with fayalite and magnetite structures were observed in the samples collected from the iron-producing furnace site, it was determined that the ironmaking process was performed. Furthermore, nonmetal inclusions and a porous $\mathrm{Fe}$ structure with low $\mathrm{C}$ content were observed together in the reduced iron samples. Therefore, it is possible that iron blooms of good quality were produced based on the direct ironmaking method(Park, 2004). Because many cracks were observed on the samples of iron ores that seemed to be used as raw material, an attempt was made to investigate the possibility of roasting. However, there was difficulty in distinguishing the size changes by pulverization or ruptures caused by preheating(Jang, 2010), and hightemperature-indicating minerals were not identified in the compound analysis results. Therefore, additional samples and preliminary analysis would be required to determine accurately whether the roasting process was performed.

The compound composition analysis of furnace wall and floor samples indicated that rubble of quartz and feldspar series was used when constructing the iron-producing furnace, because it was easy to procure nearby. Furthermore, because mullite, cristobalite, and hercynite were detected in most samples, it seemed that a high-temperature process of at least $1,050^{\circ} \mathrm{C}$ was performed inside the furnace. In addition, because magnetite was detected in the smelting slag, reduced iron, and iron ore samples, it appeared that iron ores were used as raw material.

In the analysis results of major components of the slag, a total $\mathrm{Fe}$ content value similar to the total $\mathrm{Fe}$ content of the ancient ironmaking process was derived, but the actual yield of iron did not appear to be good compared with the $\mathrm{Fe}$ content of iron ores. Considering the effects of the clay used to construct the furnace and effects of raw materials and fuels used in the operation, it would be difficult to determine with certainty whether a slag former was used in the ironmaking process(Lee et al., 2015). The clay used for the furnace construction had the component contents of regular clay rather than the characteristics of fire-resistant material(Han et al., 1993), indicating that the materials that could be easily procured nearby were used without paying much attention to corrosion resistance using the furnace constructing technique. 
It seemed that processes were performed at the Gwangyang Saengsoegol iron-producing furnace based on the direct ironmaking method to produce weapons to be used by a righteous army, in an environment where it was easy to avoid the vigilance of the Japanese and easy to procure fuel and water. Although the forging process for ironware production could not be investigated, it was confirmed that a small-scale ironmaking process was performed in short periods of time, while a mass production system could not be furnished, because of the social circumstances at that time.

This historical site is an important case of independence movement history as well as a cultural asset left by a righteous army that played an active role in Gwangyang to regain the sovereignty lost during the Japanese occupation period. Therefore, it is hoped that the study for the Gwangyang Saengsoegol iron-producing furnace will not stop at the present analysis result and that more-elaborate research will be conducted based on academic linkage between conservation science and the humanities.

\section{REFERENCES}

Choi, J., Kim, S.C. and Doh, J.M., 1994, Metallography of iron slag excavated from Bongsan-dong, Yeosu city in the period of the $16^{\text {th }}$ to $19^{\text {th }}$ century. Journal of Conservation Science, 3(1), 13-18. (in Korean with English abstract)

Chung, K.Y., 2006, Scientific analyses of iron manufacturing site at Yongmyeong-ri, Geoncheon in Gyeongju. The Journal of Cultural Heritage, 4, 119-159. (in Korean with English abstract)

Chung, K.Y., 2009, Development of parching steel material using ancient steel making technique. National Science Museum, Daejeon, 1-4. (in Korean with English abstract)

Chung, K.Y., 2001, A study of iron technologies of the three states in Korea-Through the metallurgical micro structures. Ph.D. thesis, Hongik University, Seoul. (in Korean with English abstract)

Gwangyang City Hall, 1999, Nation protection movement historical site from Gwangyang. (in Korean)

Gwangyang City Hall, 2012, Research service report of nation protection movement historical site excavation from Gwangyang. 18-21. (in Korean)

Han, S.M., Kim, K.N. and Shin, D.Y., 1993, A basic study on the refractory material of Kalcheon iron making furnace. Journal of Conservation Science, 2(2), 25-30. (in Korean with English abstract)
Hong, Y.K., 2004, A study on Honam righteous armies in the Great Han Empire. Ilchokak, Seoul, 18-20. (in Korean with English abstract)

Jang, K.S., 2010, Research of the iron making in the ancient Korea : Focus on iron ore. Yeongnam Institute of Cultural Properties, 29-45. (in Korean)

Jeonnam Cultural Property Research Center, 2011, Summary report of iron producing furnace excavation from Gwangyang. Saengsoegol. 1-5. (in Korean)

Kang, Y.H., Cho, N.C., Song, H.J. and Go, H.S., 2010, The study on material characteristics of slags excavated from iron making site. Journal of Conservation Science, 26(2), 171-182. (in Korean with English abstract)

Kim, M.J., 2017, Iron production process of slag excavated from Gwangyang Saengsoegol. Masters's thesis, Korean National University of Cultural Heritage, Buyeo. (in Korean with English abstract)

Lee, E.W., Han, J.S., Chae, M.H. and Kim, E.J., 2015, An experimental archaeological study on the Baekjae iron smelting furnace and its production process. Korean Journal of Cultural Heritage Studies, 48(4), 138-153. (in Korean with English abstract)

National Institute of Korean History, 1965, History of Korean Independence Movement. 295-296. (in Korean)

Park, J.S., 2004, Iron smelting technology of ancient Korea as observed in slag excavated from Pochen Banwol fortress. Hongik Faculty Journal, 14, 467-473. (in Korean with English abstract)

Park, J.S., Lee, Y.S., Shin, K.C. and Kim J.W., 2001, A study on the restoration of Gaya iron culture through scientific analysis of Gaya ironware remains. Gimhae Development Strategy Institute, 4(1), 39-197. (in Korean)

Rho, T.C., 2000, Study on the ancient metallurgical technology in Korea. Hakyoun, Seoul, 172-175. (in Korean with English abstract)

Shin, K.H., 2000, Iron Story in History. Steel \& Metal News, Seoul. (in Korean)

Yoon, D.S., 1986, Slags produced by ancient iron manufacture. Publish of National Academy of Sciences of Korea, 25. (in Korean)

Yoon, D.S. and Shin, K.H., 1981, Metallurgical investigations of early iron age artifacts excavated in the Han river basin. Korean Journal of Metals and Materials, 19(8), 661-674. (in Korean with English abstract)

Yoon, D.S. and Shin, K.H., 1982, Metallurgical considerations on the early iron age artifacts excavated from the pit-graves throughout the Korean peninsula. The Journal of the Korean Archaeological Society, 13, 97-134. (in Korean) 
